\title{
ANALYSIS OF VAPORS FROM METHYLENE CHLORIDE EXTRACTS OF NUCLEAR GRADE HEPA FILTER FIBERGLASS SAMPLES
}

\author{
J. M. Frye \\ H. L. Anastos \\ F. C. Gutierrez \\ Washington River Protection Solutions LLC
}

June 2012

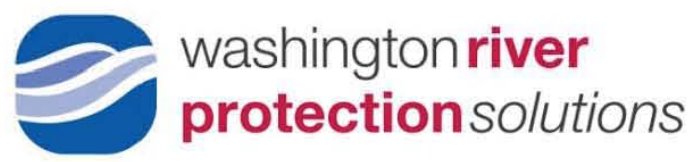

Prepared for the U. S. Department of Energy

Office of River Protection

Contract Number: DE-DE-AC2708RV14800 


\section{LAB-RPT-11-00010 Rev. 1}

\section{EXECUTIVE SUMMARY}

While several organic compounds were detected in the vapor samples used in the reenactment of the preparation of mounts from the extracts of nuclear grade high-efficiency particulate air filter fiberglass samples, the most significant species present in the samples were methylene chloride, phenol, phenol-d6, and 2-fluorophenol. These species were all known to be present in the extracts, but were expected to have evaporated during the preparation of the mounts, as the mounts appeared to be dry before any vapor was collected. These species were present at the following percentages of their respective occupational exposure limits: methylene chloride, $2 \%$; phenol, $0.4 \%$; and phenol-d6, 0.6\%. However, there is no established limit for 2-fluorophenol. Several other compounds were detected at low levels for which, as in the case of 2-fluorophenol, there are no established permissible exposure limits. These compounds include 2-chlorophenol; N-nitroso-1-propanamine; 2-fluoro-1,1'-biphenyl; 1,2-dihydroacenaphthylene; 2,5-cyclohexadiene-1,4-dione,2,6-bis(1,1-dimethylethyl)-); trimethyl oxirane; n-propylpropanamine; 2-(Propylamino)ethanol; 4-methoxy-1-butene; 6-methyl-5-hepten-2-one; and 3,4dimethylpyridine. Some of these were among those added as surrogates or spike standards as part of the Advanced Technologies and Laboratories International, Inc. preparation of the extract of the HEPA filter media and are indicated as such in the data tables in Section 2, Results; other compounds found were not previously known to be present.

The main inorganic species detected (sulfate, sodium, and sulfur) are also consistent with species added in the preparation of the methylene chloride extract of the high-efficiency particulate air sample. 
LAB-RPT-11-00010 Rev. 1

\section{Table of Contents}

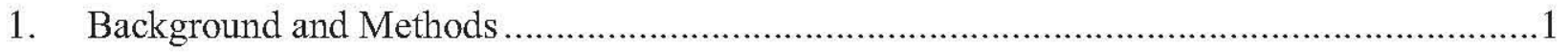

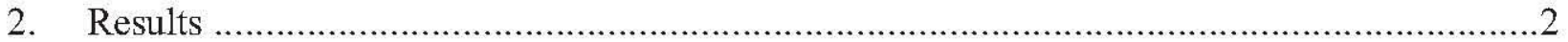

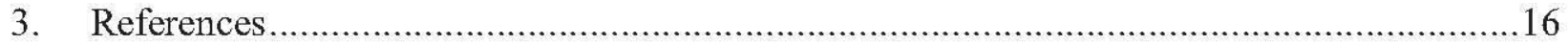

\section{List of Tables}

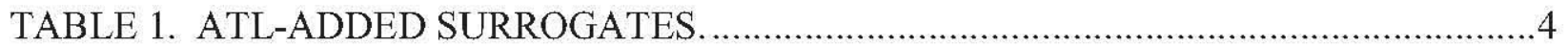

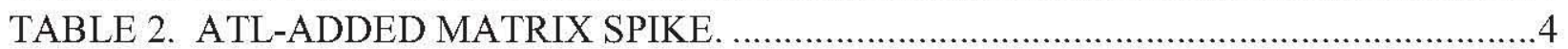

TABLE 3. RESULTS OF TEST 1 SEMI-VOLATILE TDU SAMPLES COLLECTED ON CARBOTRAPTM 150 TDU TUBES ANALYZED BY IH-LT-523-160. (2 pages) ...........5

TABLE 4. RESULTS OF TEST 1 VOA SAMPLES COLLECTED ON CARBOTRAPTM 300 TDU TUBES ANALYZED BY IH-LT-523-153. (2 pages) ……...............................

TABLE 5. RESULTS OF SVOA SAMPLES FROM TEST 2, DIRECT SPIKE OF EXTRACT ON CARBOTRAP ${ }^{\text {TM }} 150$ TDU TUBES...........................................................11

TABLE 6. RESULTS OF VOA SAMPLES FROM TEST 2, DIRECT SPIKE OF EXTRACT

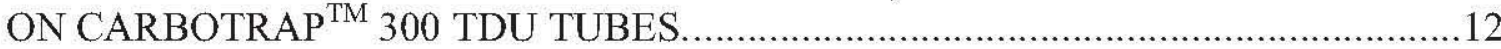

TABLE 7. RESULTS OF ION CHROMATOGRAPHIC ANALYSIS OF WATER EXTRACTS OF METHYLENE CHLORIDE EXTRACTS OF HEPA FILTER MATERIAL..............14

TABLE 8. ICP RESULTS FOR ANALYSIS OF WATER EXTRACTION OF METHYLENE CHLORIDE EXTRACTS OF HEPA FILTER MEDIA. ............................................15

\section{List of Figures}

FIGURE 1. VAPOR SAMPLING APPARATUS 3

FIGURE 2. CHROMATOGRAM OF S11R000498 (IN RED) OVERLAID WITH CHROMATOGRAM OF S11R000498 MINUS CHROMATOGRAM OF METHYLENE CHLORIDE BLANK, S11R000499 (IN BLUE). .10

FIGURE 3. OVERLAY OF S11R000510, TEST 2 VOA-3 SPIKE WITH THE CHROMATOGRAM FOR S11R00510 MINUS S11ROO511, METHYLENE CHLORIDE BLANK. 
LAB-RPT-11-00010 Rev. 1

\section{List of Terms}

\section{Abbreviations}

ALS

ATL

CA

CAS

DNPH

GC/MS

HEPA

IC

ICP

$\mathrm{IH}$

OEL

OSHA

PEL

RBA

SVOA

TDU

TIC

VOA

\section{Units}

$\begin{array}{ll}\mathrm{hr} & \text { hour } \\ \mu \mathrm{L} & \text { microliter } \\ \mathrm{M} & \text { Molar } \\ \mathrm{m} / \mathrm{e} & \text { mass to energy } \\ \mathrm{mg} & \text { milligram } \\ \mathrm{min} & \text { minutes } \\ \mathrm{mL} & \text { milliliter } \\ \mathrm{mm} & \text { millimeter } \\ \mathrm{ng} & \text { nanogram } \\ \mathrm{ppmv} & \text { parts per million volume }\end{array}$

Analytical Laboratory Services

Advanced Technologies and Laboratories International, Inc.

Contamination Area

Chemical Abstracts Service

2,4-Dinitrophenylhydrazine

Gas Chromatography/Mass Spectrometry

High-Efficiency Particulate Air

Ion Chromatography

Inductively Coupled Plasma

Industrial Hygiene

Occupational Exposure Limit

Occupational Safety and Health Administration

Personal Exposure Limit

Radiological Buffer Area

Semi-Volatile Organic Analyte

Thermal Desorption Unit

Tentatively Identified Compounds

Volatile Organic Analyte 


\section{BACKGROUND AND METHODS}

Several personnel experienced an unexpected exposure to noxious vapors at the 222-S Laboratory in January of 2011. This report documents the results of a set of experiments performed to recreate the events that led to the release of these vapors, but in a safe and controlled manner. The experimental approach is documented in LAB-PLN-11-00007, Test Plan and Procedure for the Analysis and Determination of Vaporous Products Formed via the Soxhlet Extraction of Nuclear Grade HEPA Filter Fiberglass Samples. The original exposure came when several employees smelled fumes upon opening the cover on a planchet containing dried methylene chloride sample extract during the performance of dose measurement. These planchets are routinely prepared by employees of Advanced Technologies and Laboratories International, Inc. (ATL) for the purposes of radiological dose rate measurements on samples being transferred from the contamination area $(\mathrm{CA})$ to the radiological buffer area (RBA). This measurement has routinely been performed on the bench top in 222-S room 1P1.

The sample that caused the exposure, which had been extracted and mounted on the planchet, was a methylene chloride soxhlet extraction of a portion of unused high-efficiency particulate air (HEPA) filter. It had been prepared using LA-523-138, "Soxhlet Extraction of Solid Samples for Semi-volatile Organic or PCB Analysis." This type of sample had been extracted and handled in this manner many times before without incident, but in this case a new Flanders nuclear grade HEPA filter was being analyzed.

In this study the same sample material was extracted again by ATL, and the extracts were transferred to 222-S room 4TUV, where they were stored in the refrigerator until used for the experiments in the test plan. Test 1 involved an ATL Chemical Technologist preparing the planchets in the same manner as before and allowing them to dry. The planchets were then placed inside a chamber; three chambers had been set up to handle three planchets at a time. Filtered air was pulled through each chamber and collected on three types of vapor media. Vapor tube samples were collected on Carbotrap ${ }^{\mathrm{TM}^{1}} 150$ thermal desorption unit (TDU) tubes for semi-volatile organic analyte (SVOA) analysis; Carbotrap ${ }^{\mathrm{TM}} 300$ TDU tubes for volatile organic analyte (VOA) analysis; and 2,4-Dinitrophenylhydrazine (DNPH) tubes for formaldehyde analysis. Tubes were collected from planchets that were prepared using unused methylene chloride, as well as for sample extracts. The extracts that were prepared by ATL for this experiment contained the normal surrogate, and where appropriate, the spiking standard used in LA-523-138. The results for this test are reported in units of ppmv. The volume of air used for the conversion of ng compound on TDU tube to ppmv was equal to the volume of air pulled through the tube. This volume may not be representative of the volume of air in which the compounds were dispersed during the $1 \mathrm{P} 1$ event. There is no way to accurately estimate the volume of vapor dispersion in $1 \mathrm{P} 1$.

\footnotetext{
${ }^{1}$ Carbotrap is a registered trademark of Sigma-Aldrich Co., St. Louis, Missouri.
} 


\section{LAB-RPT-11-00010 Rev. 1}

In Test 2 of the test plan, $0.5 \mu \mathrm{L}$ aliquots of the extracts were spiked directly onto Carbotrap $^{\mathrm{TM}} 150$ for SVOA analysis and Carbotrap ${ }^{\mathrm{TM}} 300$ TDU tubes for VOA analysis. The results from this test were reported in units of ng per TDU tube and are not converted to ppmv.

Tubes from Test 1 and Test 2 were analyzed for semi-volatile compounds using IH-LT-523-160, "Industrial Hygiene - Analysis of Semi-volatile Organic Compounds Collected on Thermal Desorption Tubes by Gas Chromatography/Mass Spectrometry." They were analyzed for volatile organic compounds using IH-LT-523-153, "Analysis of VOA Vapor Samples Collected on Thermal Desorption Tubes by Gas Chromatography/Mass Spectrometry." The tubes collected for formaldehyde analysis in Test 1 were analyzed at an off-site laboratory. The gas chromatography/mass spectrometry (GC/MS) method used for the analysis of the VOA samples was changed from what is normally used for industrial hygiene (IH) vapor samples; the parameters for collecting the scan information were set to collect over a narrower range of $20 \mathrm{~m} / \mathrm{e}$ to $300 \mathrm{~m} / \mathrm{e}$ to give increased sensitivity. The decision was made to include the ions for methylene chloride instead of leaving them out as had been previously discussed in order to determine how much, if any, methylene chloride vapor remained in the vapor generated from the planchets.

In Test 3, aliquots of methylene chloride were extracted with water in a separatory funnel. The water extracts were submitted to ATL for inductively coupled plasma (ICP) and ion chromatography (IC) analysis.

\section{RESULTS}

The compounds reported in Table 3 were detected in the samples from Test 1 for SVOA analysis. The compounds present in the greatest concentration in these samples were surrogate or matrix spike compounds added by ATL in the course of preparing the extracts. The blank methylene chloride was not spiked by ATL with surrogates or matrix spike, but still contained a small amount of a variety of semi-volatile compounds, the greatest of which was phenol. A milliliter of blank methylene chloride or extract was placed on a planchet marked with a Sharpie marker and allowed to dry. The dry planchet was then placed inside a chamber, and filtered air was pulled through the chamber and sampling tube at $100 \mathrm{~mL} / \mathrm{min}$ for $1 \mathrm{hr}$. The method blank analyzed with this batch of samples was free of contaminants, so detected compounds in the blank methylene chloride sample came either from the methylene chloride, the planchet, or the Sharpie marker used to mark the planchet when the mounts were prepared.

The apparatus used to contain the planchets and collect the vapor on the tubes may be seen in Figure 1. The sample pump was connected to the sample tube side of the apparatus. The air inlet side had two TDU tubes, Tenax-TA and Carbotrap ${ }^{\mathrm{TM}} 300$, to absorb any chemicals present in the hood air. Three such apparatuses were used: one for SVOA, one for VOA, and one for aldehyde. 


\section{LAB-RPT-11-00010 Rev. 1}

FIGURE 1. VAPOR SAMPLING APPARATUS.




To each sample extracted, ATL routinely adds the following compounds as surrogates.

TABLE 1. ATL-ADDED SURROGATES.

\begin{tabular}{|l|l|}
\hline Base/Neutral Surrogate Mix (Restek Cat \# 31024) & Acid Surrogate Mix (Restek Cat \# 31025) \\
\hline 2-fluorobiphenyl & 2-fluorophenol \\
\hline nitrobenzene-d5 & phenol-d6 \\
\hline p-terphenyl-d4 & $2,4,6$-tribromophenol \\
\hline
\end{tabular}

To the spiked sample extracts, ATL adds the following spike standards as well as the surrogate standards.

TABLE 2. ATL-ADDED MATRIX SPIKE.

\begin{tabular}{|l|l|}
\hline Base/Neutral Matrix Spike Mix (Restek Cat\# 31004) & Acid Matrix Spike Mix (Restek Cat\# 31014) \\
\hline acenaphthene & 4-chloro-3-methylphenol \\
\hline 1,4-dichlorobenzene & 2-chlorophenol \\
\hline 2,4-dinitrotoluene & 4-nitrophenol \\
\hline N-nitroso-di-n-propylamine & pentachlorophenol \\
\hline pyrene & phenol \\
\hline $1,2,4$-trichlorobenzene & \\
\hline
\end{tabular}


TABLE 3. RESULTS OF TEST 1 SEMI-VOLATILE TDU SAMPLES COLLECTED ON CARBOTRAPTM 150 TDU TUBES ANALYZED BY IH-LT-523-160. (2 pages)

\begin{tabular}{|c|c|c|c|c|c|c|c|}
\hline Analyte & $\begin{array}{c}\text { CAS } \\
\text { number }\end{array}$ & Type & $\begin{array}{c}\text { S11R000503 } \\
\text { Blank } \\
\text { (ppmv) }\end{array}$ & $\begin{array}{c}\text { S11R000500 } \\
\text { Headspace } \\
\text { SVOA } 1 \text { (ppmv) }\end{array}$ & $\begin{array}{c}\text { S11R000501 } \\
\text { Headspace } \\
\text { SVOA } 2 \text { (ppmv) }\end{array}$ & $\begin{array}{c}\text { S11R000502 } \\
\text { Headspace } \\
\text { SVOA 3-spike } \\
\text { (ppmv) }\end{array}$ & OEL/PEL \\
\hline dodecane & $112-40-3$ & calibrated & 0.000077 & 0.000072 & 0.000075 & 0.000089 & $200^{1}$ \\
\hline tridecane & $629-50-5$ & calibrated & 0.000112 & 0.000095 & 0.000088 & 0.000112 & $200^{1}$ \\
\hline tetradecane & $629-59-4$ & calibrated & 0.000141 & 0.000117 & 0.000111 & 0.000117 & $200^{1}$ \\
\hline hexadecane & $544-76-3$ & calibrated & nd & nd & 0.000060 & 0.000063 & $200^{1}$ \\
\hline 2-fluorophenol & $367-12-4$ & $\begin{array}{l}\text { TIC- } \\
\text { surrogate }\end{array}$ & nd & 0.002306 & 0.001615 & 0.001208 & Not known \\
\hline hexanal & $66-25-1$ & TIC & 0.000365 & nd & nd & nd & $50^{2}$ \\
\hline phenol & $108-95-2$ & TIC-spike & 0.001667 & nd & nd & 0.029696 & $5^{3}$ \\
\hline phenol-d6 & $13127-88-3$ & $\begin{array}{l}\text { TIC- } \\
\text { surrogate }\end{array}$ & nd & 0.019316 & 0.014780 & nd & $\begin{array}{c}5^{3} \\
\text { (Use same as } \\
\text { non-deuterated) }\end{array}$ \\
\hline 2-chlorophenol & $95-57-8$ & TIC-spike & nd & nd & nd & 0.001070 & Not known \\
\hline decane & $124-18-5$ & TIC & 0.000128 & nd & nd & nd & $200^{1}$ \\
\hline 2-ethyl-1-hexanol & $104-76-7$ & TIC & 0.000453 & 0.000271 & 0.000197 & 0.000213 & $50^{2}$ \\
\hline undecane & $1120-21-4$ & TIC & 0.000142 & nd & nd & nd & $200^{1}$ \\
\hline nonanal & $124-19-6$ & TIC & 0.000276 & nd & nd & nd & $50^{2}$ \\
\hline N-nitroso-1-propanamine & $621-64-7$ & TIC-spike & nd & nd & nd & 0.001134 & Not known \\
\hline nitrobenzene-d5 & $4165-60-0$ & $\begin{array}{l}\text { TIC- } \\
\text { surrogate }\end{array}$ & nd & 0.001622 & 0.001844 & 0.002069 & $1^{3}$ \\
\hline 1,2,4-trichlorobenzene & $120-82-1$ & TIC-spike & nd & nd & nd & 0.000442 & $5^{4}$ \\
\hline benzothiazole & $95-16-9$ & TIC & 0.000183 & 0.000167 & 0.000194 & 0.000257 & $1^{2}$ \\
\hline pentadecane & $629-62-9$ & TIC & 0.000253 & nd & nd & 0.000234 & $200^{1}$ \\
\hline 2,6,11-trimethyldodecane & $31295-56-4$ & TIC & 0.000271 & 0.000242 & nd & 0.000219 & $200^{1}$ \\
\hline 5-ethyl-2-methyl octane & $62016-18-6$ & TIC & 0.000194 & 0.000291 & nd & 0.000163 & $200^{1}$ \\
\hline 2-fluoro-1,1'-biphenyl & $321-60-8$ & TIC & nd & 0.000235 & 0.000171 & 0.000256 & Not known \\
\hline $\begin{array}{l}\text { 1,2-dihydroacenaphthylene } \\
\text { (acenaphthene) }\end{array}$ & $83-32-9$ & TIC-spike & nd & nd & nd & 0.000154 & $\begin{array}{c}\text { Not known, Class } 3 \\
\text { carcinogen }\end{array}$ \\
\hline 4, 6-dimethyldodecane & $61141-72-8$ & $\mathrm{TIC}$ & 0.000115 & nd & 0.000212 & nd & $200^{1}$ \\
\hline
\end{tabular}


TABLE 3. RESULTS OF TEST 1 SEMI-VOLATILE TDU SAMPLES COLLECTED ON CARBOTRAPTM 150 TDU TUBES ANALYZED BY IH-LT-523-160. (2 pages)

\begin{tabular}{|c|c|c|c|c|c|c|c|}
\hline Analyte & $\begin{array}{c}\text { CAS } \\
\text { number }\end{array}$ & Type & $\begin{array}{c}\text { S11R000503 } \\
\text { Blank } \\
\text { (ppmv) }\end{array}$ & $\begin{array}{c}\text { S11R000500 } \\
\text { Headspace } \\
\text { SVOA } 1 \text { (ppmv) } \\
\end{array}$ & $\begin{array}{l}\text { S11R000501 } \\
\text { Headspace } \\
\text { SVOA } 2 \text { (ppmv) } \\
\end{array}$ & $\begin{array}{c}\text { S11R000502 } \\
\text { Headspace } \\
\text { SVOA 3-spike } \\
\text { (ppmv) }\end{array}$ & OEL/PEL \\
\hline $\begin{array}{l}\text { 2,5-cyclohexadiene-1,4- } \\
\text { dione,2,6-bis( } 1,1- \\
\text { dimethylethyl)-) }\end{array}$ & $719-22-2$ & TIC & 0.000096 & nd & nd & nd & Not known \\
\hline docosane & $629-97-0$ & TIC & 0.000076 & nd & 0.000064 & 0.000071 & $200^{1}$ \\
\hline
\end{tabular}

$\mathrm{CAS}=\quad$ Chemical Abstracts Service

nd $=$ not detected

OEL/PEL $=\quad$ Occupational Exposure Limit/Personal Exposure Limit

ppmv = parts per million vapor

TIC = Tentatively identified compound

${ }^{1}$ RPP-22491, Industrial Hygiene Chemical Vapor Technical Basis (Table C-).

${ }^{2}$ PNNL-15640, Screening Values for Non-Carcinogenic Hanford Waste Tank Vapor Chemicals that Lack Established Occupational Exposure Limits.
${ }^{3}$ United States Department of Labor and Industries Occupational Safety and Health Administration (OSHA) Standard 29 CFR Number 1910.1000, Tab

Contaminants," www.osha.gov/pls/oshawweb/owadisp.show document?p table=standards\&p id=9992.

${ }^{4}$ NIOSH Pocket Guide to Chemical Hazards, Publication \#2005-149. (Recommended Exposure Limit [NIOSH REL.])

The results from the TDU analyses were converted from ng per tube to ppmv using the volume of air collected and the molecular weights of the compounds as found in the NIST WebBook (NIST Chemistry WebBook, NIST Standard Reference Database Number 69, National Institute of Standards and Technology, http://webbook.nistgov/chemistry/). The raw data and calculations may be found in the raw data reports for OmniLIMS group 20111101 for semi-volatile and volatile analysis. Phenol and phenol-d6 have the same retention time on the column. Both are present in S11R000500 to S11R000502 because phenol-d6 is one of the compounds added to each sample when ATL prepares an extract. In some cases the GC/MS picked up the phenol as the predominant peak; in others it picked up phenol-d6 as the predominant species. 
The volatile organic compounds found in the VOA samples collected on Carbotrap ${ }^{\text {TM }} 300$ TDU tubes in Test 1 are listed in Table 4 , below.

TABLE 4. RESULTS OF TEST 1 VOA SAMPLES COLLECTED ON CARBOTRAPTM 300 TDU TUBES ANALYZED BY IH-LT-523-153. (2 pages)

\begin{tabular}{|c|c|c|c|c|c|c|c|}
\hline Analyte & $\begin{array}{c}\text { CAS } \\
\text { Number }\end{array}$ & Type & $\begin{array}{c}\text { S11R000499 } \\
\text { (Solvent } \\
\text { Blank) } \\
\text { (ppmv) }\end{array}$ & $\begin{array}{c}\text { S11R000496 } \\
\text { Headspace } \\
\text { VOA } 1 \text { (ppmv) }\end{array}$ & $\begin{array}{c}\text { S11R000497 } \\
\text { Headspace } \\
\text { VOA } 2 \text { (ppmv) }\end{array}$ & $\begin{array}{c}\text { S11R000498 } \\
\text { Headspace } \\
\text { VOA 3-spike } \\
\text { (ppmv) }\end{array}$ & $\begin{array}{c}\text { Air Exposure } \\
\text { Limit } \\
\text { (ppmv) }\end{array}$ \\
\hline acetonitrile & $75-05-8$ & calibrated & 0.029053 & nd & nd & nd & $40^{1}$ \\
\hline 2-hexanone & $591-78-6$ & calibrated & 0.000190 & nd & nd & nd & $100^{1}$ \\
\hline 1-butanol & $71-36-3$ & $\begin{array}{l}\text { calibrated } \\
\text { (Sharpie) }\end{array}$ & 0.002878 & 0.001722 & 0.001577 & 0.006134 & $100^{1}$ \\
\hline 3-buten-2-one & $78-94-4$ & calibrated & 0.000380 & 0.000731 & 0.000778 & 0.001039 & $0.2^{2}$ \\
\hline ethanol & $64-17-5$ & TIC-Sharpie & 0.005857 & nd & nd & nd & $1000^{1}$ \\
\hline methylene chloride & $75-09-2$ & $\begin{array}{l}\text { TIC-solvent } \\
\text { of extract }\end{array}$ & 0.083560 & 0.457946 & 0.430617 & 0.497682 & $25^{3}$ \\
\hline trimethyl oxirane & $5076-19-7$ & TIC & nd & nd & nd & 0.001635 & Not Known \\
\hline acetic acid & $64-19-7$ & TIC & nd & 0.000639 & 0.002643 & nd & $10^{1}$ \\
\hline hexane & $110-54-3$ & TIC & 0.013042 & nd & nd & nd & $500^{1}$ \\
\hline 3-methyl-2-butanone & $563-80-4$ & TIC & nd & 0.001146 & 0.0015124 & 0.002099 & $200^{4}$ \\
\hline 2-pentanone & $107-87-9$ & TIC & nd & 0.002144 & 0.0035981 & 0.004360 & $200^{4}$ \\
\hline 3-pentanone & $96-22-0$ & TIC & nd & 0.00168 & 0.0030942 & 0.004060 & $200^{4}$ \\
\hline tridecane & $629-50-5$ & TIC & nd & nd & 0.000271 & nd & $200^{4}$ \\
\hline heneicosane & $629-94-7$ & TIC & nd & 0.000232 & nd & nd & $200^{4}$ \\
\hline n-propyl-propanamine & $142-84-7$ & TIC-spike & nd & nd & nd & 0.002282 & Not Known \\
\hline 2-(Propylamino)ethanol & $16369-21-4$ & TIC & nd & nd & nd & 0.000633 & Not Known \\
\hline 4-methoxy-1-butene & $4696-30-4$ & TIC & nd & nd & nd & 0.000868 & Not Known \\
\hline hexadecane & $544-76-3$ & TIC & nd & 0.000768 & nd & 0.000341 & $200^{4}$ \\
\hline 1-propanol & $71-23-8$ & TIC-Sharpie & 0.001607 & nd & nd & nd & $200^{4}$ \\
\hline pentenal & $110-62-3$ & TIC & 0.000439 & nd & nd & nd & $50^{2}$ \\
\hline decane & $124-18-5$ & TIC & 0.000459 & nd & nd & nd & $200^{4}$ \\
\hline 1,2,3-trimethylbenzene & $526-73-8$ & TIC & 0.000152 & nd & nd & $\mathrm{nd}$ & $25^{5}$ \\
\hline dl-limonene & $138-86-3$ & TIC & 0.000171 & 0.000266 & nd & nd & Not Regulated \\
\hline
\end{tabular}


TABLE 4. RESULTS OF TEST 1 VOA SAMPLES COLLECTED ON CARBOTRAPTM 300 TDU TUBES ANALYZED BY IH-LT-523-153. (2 pages)

\begin{tabular}{|c|c|c|c|c|c|c|c|}
\hline Analyte & $\begin{array}{c}\text { CAS } \\
\text { Number }\end{array}$ & Type & $\begin{array}{c}\text { S11R000499 } \\
\text { (Solvent } \\
\text { Blank) } \\
\text { (ppmv) }\end{array}$ & $\begin{array}{c}\text { S11R000496 } \\
\text { Headspace } \\
\text { VOA } 1 \text { (ppmv) }\end{array}$ & $\begin{array}{c}\text { S11R000497 } \\
\text { Headspace } \\
\text { VOA } 2 \text { (ppmv) }\end{array}$ & $\begin{array}{l}\text { S11R000498 } \\
\text { Headspace } \\
\text { VOA 3-spike } \\
\text { (ppmv) }\end{array}$ & $\begin{array}{c}\text { Air Exposure } \\
\text { Limit } \\
\text { (ppmv) }\end{array}$ \\
\hline 6-methyl-5-hepten-2-one & $110-93-0$ & TIC & 0.000358 & nd & nd & nd & Not Known \\
\hline undecane & $1120-21-4$ & TIC & 0.000265 & 0.000234 & nd & nd & $200^{4}$ \\
\hline 2-ethyl-1-hexanol & $104-76-7$ & TIC & 0.000311 & nd & nd & nd & $50^{6}$ \\
\hline 2-fluorophenol & $367-12-4$ & $\begin{array}{l}\text { TIC- } \\
\text { surrogate }\end{array}$ & nd & 0.015641 & 0.019514 & 0.020392 & Not Known \\
\hline 3,4-dimethylpyridine & $583-58-4$ & TIC & nd & nd & 0.000579 & nd & Not Known \\
\hline N,N-dimethylacetamide & $127-19-5$ & TIC & nd & nd & 0.000836 & 0.001123 & $10^{1}$ \\
\hline 2,4,5,6-D5-aniline & $4165-61-1$ & TIC & nd & 0.00352 & 0.002594 & 0.003108 & $5^{1}$ \\
\hline phenol & $108-95-2$ & TIC-spike & 0.001950 & nd & nd & 0.015909 & $5^{1}$ \\
\hline 2-chlorophenol & $95-57-8$ & TIC-spike & nd & nd & nd & 0.015134 & Not Known \\
\hline phenol-d6 & $4165-62-2$ & $\begin{array}{l}\text { TIC- } \\
\text { surrogate }\end{array}$ & nd & 0.022985 & 0.026410 & 0.025889 & $5^{1}$ \\
\hline dodecane & $112-40-3$ & TIC & 0.000125 & nd & nd & nd & $200^{4}$ \\
\hline nonanal & $124-19-6$ & TIC & 0.000523 & nd & 0.000407 & nd & $50^{6}$ \\
\hline
\end{tabular}

United States Department of Labor and Industries, OSHA Standard 29 CFR Number 1910.1000, Table Z-1, "Limits for Air Contaminants,"

www. osha.gov/pls/oshawweb/owadisp.show document?p table $=$ standards\&p id $=9992$

${ }^{2} 2011$ TLVS $^{\circledR}$ and BEIs ${ }^{\circledR}$, ACGIH Publication $\# 0111$.

${ }^{3}$ United States Department of Labor and Industries, OSHA Standard 29 CFR Number 1910.1052, "Methylene Chloride," Appendix A,

www.osha.gov/pls/oshaweb/owadisp.show document?p table=STANDARDS\&p id=10094

${ }^{4}$ RPP-22491, "Industrial Hygiene Chemical Vapor Technical Basis" (Table C-).

"NIOSH Pocket Guide to Chemical Hazards, Publication \#2005-149. (Recommended Exposure Limit [NIOSH REL]).

${ }^{6}$ PNNL-15640, Screening Values for Non-Carcinogenic Hanford Waste Tank Vapor Chemicals that Lack Established Occupational Exposure Limits.

Some compounds that were detected in the samples were not reported. These include compounds added as internal standards in the analysis of the TDU tubes. For SVOA analysis, these compounds were 1,4-dichlorobenzene-d4, naphthalene-d8, phenanthrene-d10, chrysene-d12, and perylene-d12. In the same manner, the reported compounds for the VOA analysis did not include internal standard 
compounds 1,4-dichlorobenzene-d4, fluorobenzene, and chlorobenzene-d5. If the matrix spike compound 1,4-dichlorobenzene was detected, it may have been labeled as 1,4-dichlorobenzene-d4 and not reported.

The air exposure limits in Tables 3 and 4 make the assumption that deuterated versions of a chemical have the same exposure limits as the undeuterated compound. Not all of the compounds found have data available on the exposure limits.

The chromatogram for the methylene chloride blank for Test 1 (S11R000499, 11121310.D) was subtracted from the chromatogram from the VOA 3 spiked sample (S11R000498, 11121313.D). The subtracted chromatogram, overlaid on the original chromatogram for VOA 3, may be seen below in Figure 2. 
FIGURE 2. CHROMATOGRAM OF S11R000498 (IN RED) OVERLAID WITH CHROMATOGRAM OF S11R000498 MINUS CHROMATOGRAM OF METHYLENE CHLORIDE BLANK, S11R000499 (IN BLUE).
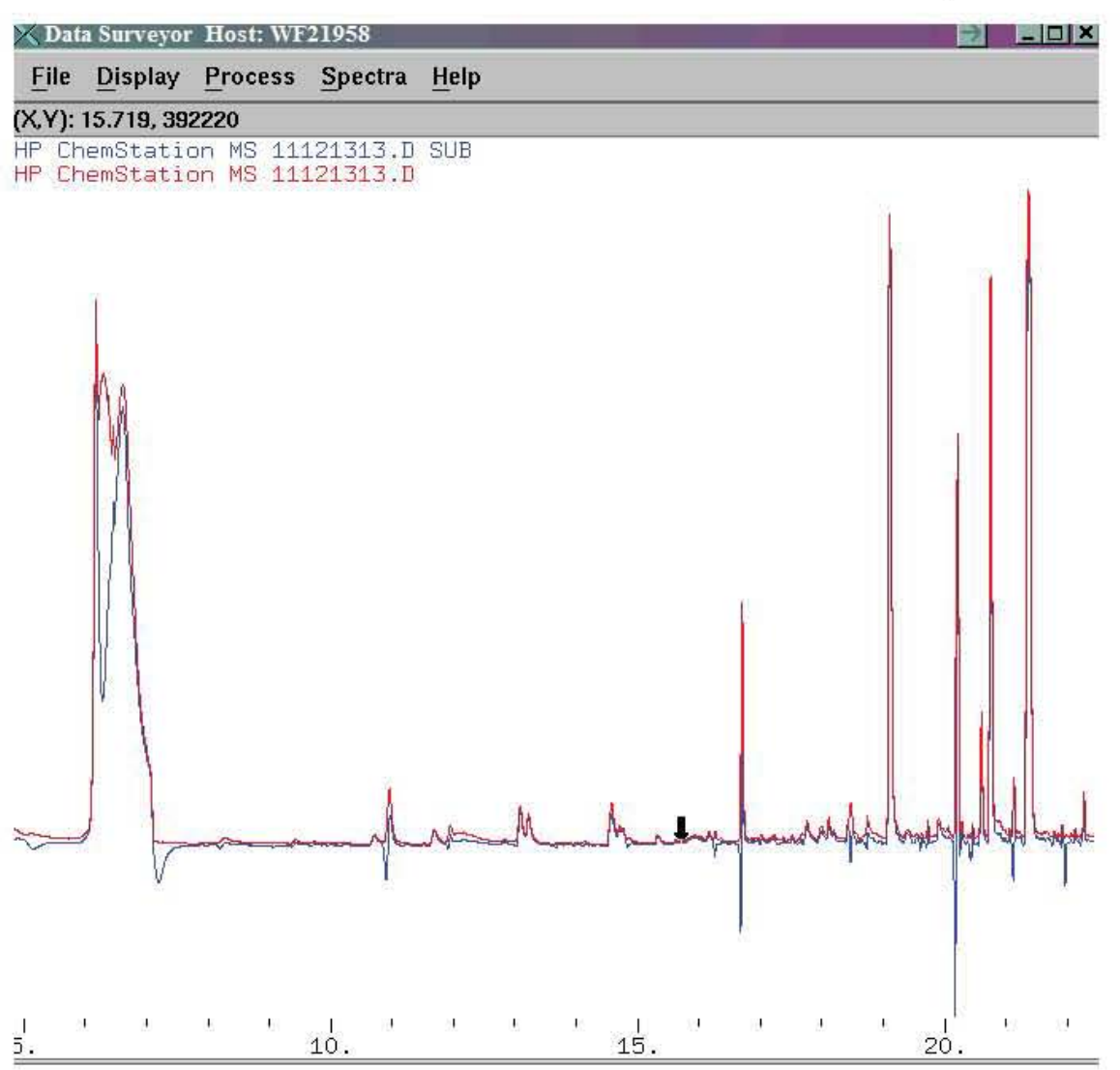

Samples for formaldehyde analysis were also collected during Test 1 . The vapors were collected on 2,4 -dinitrophenylhydrazineimpregnated silica gel tubes. These were sent offsite for analysis at Analytical Laboratory Services (ALS) in Salt Lake City, Utah. No formaldehyde was detected in these samples, all were reported at less than $0.10 \mu \mathrm{g} / \mathrm{sample}$.

Test 2 involved spiking $0.5 \mu \mathrm{L}$ of extract or blank methylene chloride directly onto a TDU tube. Internal standard for the TDU method was also spiked onto the tube, and the tubes were analyzed as in Test 1 by GC/MS. Formaldehyde tubes were not prepared for Test 2. The results for Test 2 are reported in ng analyte per tube. Since these were not vapor samples, no conversion to ppmv was performed. 
The total amount of sample used per tube in Test 2 was much smaller than the amount loaded on each tube in Test 1 . In Test 1 the vapors released by $1 \mathrm{~mL}$ of sample were collected on one tube. In Test 2, $0.5 \mu \mathrm{L}$ of extract was placed on each tube. Calibrated compounds that were not detected are not reported below. Internal standard compounds used in the course of analysis of the TDU tubes are also not reported.

TABLE 5. RESULTS OF SVOA SAMPLES FROM TEST 2, DIRECT SPIKE OF EXTRACT ON CARBOTRAPTM 150 TDU TUBES.

\begin{tabular}{|c|c|c|c|c|c|c|}
\hline Analyte & $\begin{array}{c}\text { CAS } \\
\text { Number }\end{array}$ & Type & $\begin{array}{l}\text { S11R000515 } \\
\text { (Blank) (ng) }\end{array}$ & $\begin{array}{l}\text { S11R000512 } \\
\text { SVOA 1- (ng) }\end{array}$ & $\begin{array}{l}\text { S11R000513 } \\
\text { SVOA 2- (ng) }\end{array}$ & $\begin{array}{l}\text { S11R000514 } \\
\text { SVOA 3-spike } \\
\text { (ng) }\end{array}$ \\
\hline 2-fluorophenol & $367-12-4$ & $\begin{array}{l}\text { TIC- } \\
\text { surrogate }\end{array}$ & 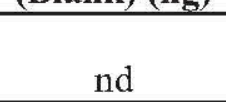 & 5.9504 & 5.2407 & 5.0294 \\
\hline 2-butoxy-ethanol & $111-76-2$ & $\mathrm{TIC}$ & 25.6994 & 15.8146 & 10.6471 & 9.9255 \\
\hline phenol & $108-95-2$ & TIC-spike & nd & nd & nd & 13.6009 \\
\hline phenol-d6 & $4165-62-2$ & $\begin{array}{l}\text { TIC- } \\
\text { surrogate }\end{array}$ & nd & 8.8993 & 7.6115 & nd \\
\hline 2-chlorophenol & $95-57-8$ & TIC-spike & nd & nd & nd & 5.5656 \\
\hline 4-chloro-3-methylphenol & $59-50-7$ & TIC-spike & nd & nd & nd & 5.7480 \\
\hline 2-fluoro-1,1-biphenyl & $321-60-8$ & $\begin{array}{l}\text { TIC- } \\
\text { surrogate }\end{array}$ & nd & 6.2607 & 5.9372 & 5.4749 \\
\hline acenaphthene & $83-32-9$ & TIC-spike & nd & nd & nd & 5.7411 \\
\hline pyrene & $129-00-0$ & TIC-spike & nd & nd & nd & 10.0899 \\
\hline p-terphenyl-d14 & $1718-51-0$ & $\begin{array}{l}\text { TIC- } \\
\text { surrogate }\end{array}$ & nd & 11.0398 & 10.3184 & 8.2783 \\
\hline $\begin{array}{l}\text { bis-(2-ethyl)-1,2- } \\
\text { benzenedicarboxylic acid }\end{array}$ & $117-81-7$ & TIC & nd & 85.0993 & 79.8893 & 75.8760 \\
\hline
\end{tabular}


TABLE 6. RESULTS OF VOA SAMPLES FROM TEST 2, DIRECT SPIKE OF EXTRACT ON CARBOTRAP ${ }^{\text {TM }} 300$ TDU TUBES.

\begin{tabular}{|c|c|c|c|c|c|c|}
\hline Analyte & $\begin{array}{c}\text { CAS } \\
\text { Number }\end{array}$ & Type & $\begin{array}{l}\text { S11R000511 } \\
\text { (Blank) (ng) }\end{array}$ & $\begin{array}{l}\text { S11R000508 } \\
\text { VOA } 1 \text { (ng) }\end{array}$ & $\begin{array}{l}\text { S11R000509 } \\
\text { VOA } 2 \text { (ng) }\end{array}$ & $\begin{array}{c}\text { S11R000510 } \\
\text { VOA 3-spike } \\
\text { (ng) }\end{array}$ \\
\hline methylene chloride & $75-09-2$ & $\mathrm{TIC}$ & 1130.2463 & 1034.2262 & 11378.094 & 1066.2446 \\
\hline methyl isobutyl ketone & $108-10-1$ & $\mathrm{TIC}$ & 6.4689 & nd & nd & nd \\
\hline 2-butoxy-ethanol & $111-76-2$ & $\mathrm{TIC}$ & 18.5513 & nd & nd & nd \\
\hline decane & $124-18-5$ & $\mathrm{TIC}$ & nd & 11.4964 & $\mathrm{nd}$ & 10.8150 \\
\hline 2-fluorophenol & $367-12-4$ & $\begin{array}{l}\text { TIC- } \\
\text { surrogate }\end{array}$ & nd & 9.8691 & 9.6746 & 10.9985 \\
\hline undecane & $1120-21-4$ & $\mathrm{TIC}$ & nd & 10.4079 & 10.0453 & 11.2601 \\
\hline 2-chlorophenol & $95-57-8$ & TIC-spike & nd & nd & nd & 8.2309 \\
\hline phenol & $108-95-2$ & $\mathrm{TIC}$ & nd & 7.9916 & 9.5631 & 22.7215 \\
\hline dodecane & $112-40-3$ & $\mathrm{TIC}$ & nd & 6.1328 & 6.8960 & 8.4660 \\
\hline
\end{tabular}

The compounds present in Test 2 SVOA analysis (Table 5) are from surrogate or spike standards except for bis-(2-ethyl)-1,2-

benzenecicarboxylic acid. This compound is also known as dioctyl phthalate. It has a low vapor pressure, $1.4 \mathrm{X} 10^{-6} \mathrm{~mm} \mathrm{Hg}$ at $25^{\circ} \mathrm{C}$, with almost no odor. It is a widely used plasticizer and paper coating in industrial, commercial, medical, and consumer products. Its OSHA PEL is $5 \mathrm{mg} / \mathrm{M}^{3}, 10 \mathrm{mg} / \mathrm{M}^{3}$. Recently there have been concerns raised about potential negative health effects caused by this chemical that have encouraged industries to find a safer alternative. Because of its low vapor pressure and the fact that it was not detected in Test 1 SVOA analysis, it was not considered as a major contributor to the vapor released by the planchets or the odor detected.

Figure 3, below, is an overlay of the chromatogram for S11R000510, Test 2 VOA-3 spike (11112820.D) with the chromatogram of S11R000510 minus S11R000511 (11112817.D), the methylene chloride blank. The original is shown in red, and the subtracted chromatogram is shown in blue. The major peaks are the same in both chromatograms, and the negative spikes in the subtracted chromatogram are due to differences in the amount of compounds present. 
FIGURE 3. OVERLAY OF S11R000510, TEST 2 VOA-3 SPIKE WITH THE CHROMATOGRAM FOR S11R00510 MINUS S11ROO511, METHYLENE CHLORIDE BLANK.

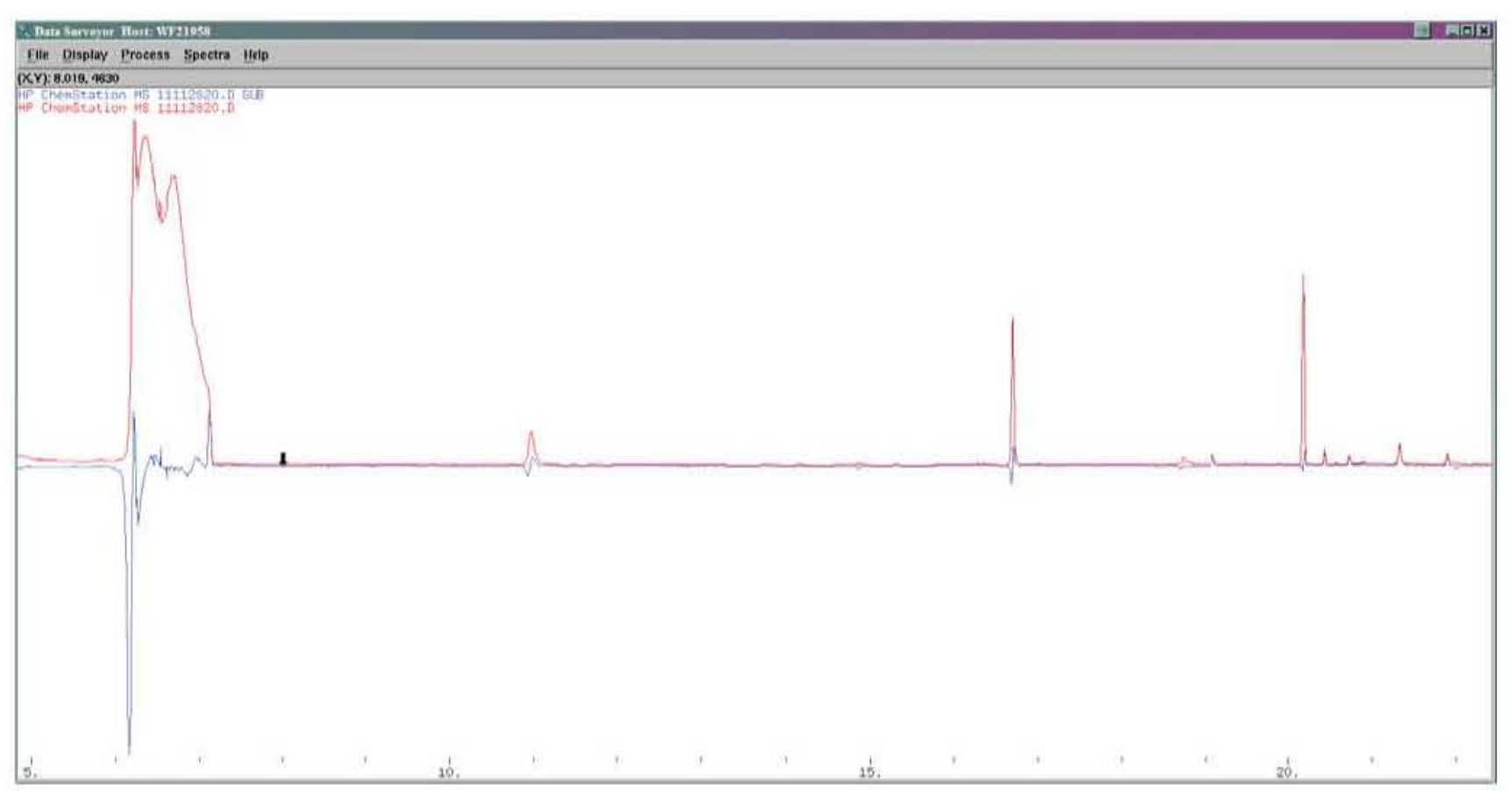

Test 3 involved extracting methylene chloride with reagent $\mathrm{Q}$ water. A 2-mL aliquot of blank methylene chloride was extracted three times with 8-mL aliquots of water, and the water was collected for analysis as samples S11R000450 and S11R000453. A 2-mL aliquot of methylene chloride extract was also extracted three times with 8-mL aliquots of water, and the water was collected for analysis as samples S11R000449 and S11R000452. Water from the same source as that used for the extraction was also submitted as samples S11R000451 and S11R000454 as an experimental control. These samples were submitted for analysis by IC for ammonium and anions, and ion-coupled plasma for metals. Only anions that were detected in at least one sample are reported in Table 7 below. 
TABLE 7. RESULTS OF ION CHROMATOGRAPHIC ANALYSIS OF WATER EXTRACTS OF METHYLENE CHLORIDE EXTRACTS OF HEPA FILTER MATERIAL.

\begin{tabular}{|l|c|c|c|}
\hline \multicolumn{1}{c|}{ Analyte } & $\begin{array}{c}\text { S11R000450 Methylene } \\
\text { Chloride Blank }(\boldsymbol{\mu g} / \mathbf{m L})\end{array}$ & $\begin{array}{c}\text { S11R000449 Methylene } \\
\text { Chloride Extract Sample } \\
(\boldsymbol{\mu} \mathrm{g} / \mathbf{m L})\end{array}$ & $\begin{array}{c}\text { S11R000451 Water Used in } \\
\text { Extraction }(\boldsymbol{\mu g} / \mathbf{m L})\end{array}$ \\
\hline fluoride & $4.1200 \mathrm{E}-03$ & $7.6600 \mathrm{E}-03$ & $2.1900 \mathrm{E}-03$ \\
\hline acetate & $<6.0400 \mathrm{E}-03$ & $1.3628 \mathrm{E}-01$ & $<6.0400 \mathrm{E}-03$ \\
\hline formate & $4.1630 \mathrm{E}-02$ & $4.9510 \mathrm{E}-02$ & $6.0530 \mathrm{E}-02$ \\
\hline chloride & $7.2810 \mathrm{E}-02$ & $8.0450 \mathrm{E}-02$ & $3.2060 \mathrm{E}-02$ \\
\hline sulfate & $7.8180 \mathrm{E}-02$ & $1.1723 \mathrm{E}+01$ & $6.7780 \mathrm{E}-02$ \\
\hline nitrate & $<2.0800 \mathrm{E}-02$ & $3.6840 \mathrm{E}-02$ & $4.2040 \mathrm{E}-02$ \\
\hline ammonium & $<1.2000 \mathrm{E}-02$ & $<1.2000 \mathrm{E}-02$ & $<1.2000 \mathrm{E}-02$ \\
\hline
\end{tabular}

The IC results show an increased amount of sulfate in the water extract as compared to what was present in the extraction of the methylene chloride extract sample or the control sample. This is probably due to the fact that anhydrous sodium sulfate is used to dry the methylene chloride extract. The amount listed in Table 7 is the concentration in the water extract. The amount of sulfate in the methylene chloride extract is $140 \mu \mathrm{g} / \mathrm{mL}$.

The ICP results on these extracts may be seen below. Only metals that were detected in at least one sample are reported in Table 8 . 
TABLE 8. ICP RESULTS FOR ANALYSIS OF WATER EXTRACTION OF METHYLENE CHLORIDE EXTRACTS OF HEPA FILTER MEDIA.

\begin{tabular}{|c|c|c|c|}
\hline Analyte & $\begin{array}{l}\text { S11R000453 Methylene } \\
\text { Chloride Blank }(\mu \mathrm{g} / \mathrm{mL})\end{array}$ & $\begin{array}{c}\text { S11R000452 Methylene } \\
\text { Chloride Extract Sample } \\
(\mu \mathrm{g} / \mathrm{mL})\end{array}$ & $\begin{array}{l}\text { S11R000454 Water Used in } \\
\text { Extraction }(\mu \mathrm{g} / \mathrm{mL})\end{array}$ \\
\hline arsenic & $3.8000 \mathrm{E}-01$ & $<2.5000 \mathrm{E}-01$ & $2.6446 \mathrm{E}-01$ \\
\hline boron & $1.8886 \mathrm{E}+00$ & $1.7751 \mathrm{E}+00$ & $2.0158 \mathrm{E}+00$ \\
\hline calcium & $<2.5000 \mathrm{E}-01$ & $<2.5000 \mathrm{E}-01$ & $4.3347 \mathrm{E}-01$ \\
\hline sodium & $2.9298 \mathrm{E}+00$ & $7.8753 \mathrm{E}+00$ & $3.5994 \mathrm{E}+00$ \\
\hline praseodymium & $1.0764 \mathrm{E}-01$ & $6.1070 \mathrm{E}-02$ & $<5.0000 \mathrm{E}-01$ \\
\hline sulfur & $<5.0000 \mathrm{E}-01$ & $2.9099 \mathrm{E}+00$ & $<5.0000 \mathrm{E}-01$ \\
\hline antimony & $<2.5000 \mathrm{E}-01$ & $2.8523 \mathrm{E}-01$ & $<2.5000 \mathrm{E}-01$ \\
\hline silicon & $2.4051 \mathrm{E}+00$ & $2.3023 \mathrm{E}-01$ & $8.8230 \mathrm{E}-01$ \\
\hline $\operatorname{tin}$ & $2.6101 \mathrm{E}+00$ & $2.4180 \mathrm{E}+00$ & $4.1476 \mathrm{E}-01$ \\
\hline uranium & $5.8184 \mathrm{E}-01$ & $<5.0000 \mathrm{E}-01$ & $<5.0000 \mathrm{E}-01$ \\
\hline zirconium & $<2.5000 \mathrm{E}-02$ & $<2.5000 \mathrm{E}-02$ & $2.7960 \mathrm{E}-02$ \\
\hline
\end{tabular}

The only species detected in appreciable quantity in the sample extract S11R000452 as compared to either the blank methylene chloride extract sample (S11R000453) or the control sample (S11R000454) were sodium and sulfur. Sodium was present in the methylene chloride extract at $94.5 \mu \mathrm{g} / \mathrm{mL}$, and the sulfur (from sulfate) was present at $34.9 \mu \mathrm{g} / \mathrm{mL}$. These levels are consistent with the IC results and reflect the traces of sodium sulfate left in the methylene chloride extract during preparation. The rest of the elements detected were present in similar quantities in the blank and in the sample extracts. Since the boron and silicon are also present in the blank, it may be assumed that they came from the glassware used to prepare the water extract. The rest of the species are present just above detection limits. 


\section{REFERENCES}

2011 TLVS $^{\circledR}$ and BEIs ${ }^{\circledR}$, ACGIH publication $\# 0111,2011$, American Conference of Governmental Industrial Hygiene Signature Publications, Cincinnati, Ohio.

IH-LT-523-153, as revised, "Analysis of VOA Vapor Samples Collected on Thermal Desorption Tubes by Gas Chromatography/Mass Spectrometry," Washington River Protection Solutions LLC, Richland, Washington.

IH-LT-523-160, as revised, "Industrial Hygiene - Analysis of Semi-volatile Organic Compounds Collected on Thermal Desorption Tubes by Gas Chromatography/Mass Spectrometry," Washington River Protection Solutions LLC, Richland, Washington.

LA-523-138, as revised, "Soxhlet Extraction of Solid Samples for Semi-volatile Organic or PCB Analysis," Advanced Technologies and Laboratories International, Inc., Richland Washington.

LAB-PLN-11-00007, 2011, Test Plan and Procedure for the Analysis and Determination of Vaporous Products Formed via the Soxhlet Extraction of Nuclear Grade HEPA Filter Fiberglass Samples, Washington River Protection Solutions LLC, Richland, Washington.

NIOSH Pocket Guide to Chemical Hazards, Publication \#2005-149, 2005, Centers for Disease Control and Prevention, Atlanta, Georgia.

NIST Chemistry WebBook, NIST Standard Reference Database Number 69, National Institute of Standards and Technology, http://webbook.nistgov/chemistry/.

PNNL-15640, 2006, Screening Values for Non-Carcinogenic Hanford Waste Tank Vapor Chemicals that Lack Established Occupational Exposure Limits, Pacific Northwest National Laboratory, Richland, Washington.

RPP-22491, 2006, Industrial Hygiene Chemical Vapor Technical Basis, Rev. 1, CH2M Hill Hanford Group, Inc., Richland, Washington.

United States Department of Labor and Industries, OSHA Standard 29 CFR Number 1910.1000, Table Z-1,'Limits for Air Contaminants," www.osha.gov/pls/oshawweb/owadisp.show document?p table=standards\&p id=9992.

United States Department of Labor and Industries, OSHA Standard 29 CFR Number 1910.1052, "Methylene Chloride," Appendix A, www.osha.gov/pls/oshaweb/owadisp.show document?p table=STANDARDS\&p id $=10$ $\underline{094}$. 


\section{Electronically Approved by:}

UserName: Frye, Jann (h0049995)

Title: APD Chemist

Date: Monday, 04 June 2012, 08:01 AM Pacific Time

Meaning: Approved by the author or delegate

UserName: Hansen, Daniel (h0039849)

Title:

Date: Monday, 04 June 2012, 08:48 AM Pacific Time

Meaning: Approved by the customer or delegate

UserName: Prilucik, John (h0074710)

Title: Analytical Project Management, Manager

Date: Monday, 04 June 2012, 01:08 PM Pacific Time

Meaning: Approved by the Group Manager or delegate 